\title{
Cytological and Immunological Examination of Cerebrospinal Fluid in 9 Patients with Ramsay Hunt's Syndrome
}

\author{
Shozo Nakamura, Sadao Takase, Katsuya Itahara, \\ Masayoshi Ogata* and Shiro Shigeta $\dagger$ \\ Division of Clinical Neurology, Institute of Brain Diseases, \\ Tohoku University School of Medicine, Sendai 980, *Central \\ Clinical Laboratory, Fukushima Medical College, Fukushima \\ 960 and $\dagger$ Department of Bacteriology, Fukushima Medical \\ College, Fukushima 960
}

\begin{abstract}
Nakamura, S., Takase, S., Itahara, K., Ogata, M. and Shigeta, S. Cytological and Immunological Examination of Cerebrospinal Fluid in 9 Patients with Ramsay Hunt's Syndrome. Tohoku J. exp. Med., 1981, 133 (2), 121-128 — The purpose of the present study was to carry out the immunological and cytological examination of cerebrospinal fluid in 9 patients with Ramsay Hunt's syndrome. The results obtained were as follows: Among the serum immunoglobulins, IgG in 1 and $\operatorname{IgM}$ in 5 of 9 cases increased. The Varicella Zoster antibody titer was significantly elevated in sera of all 9 cases and in CSF of all 7 examined cases. There was positive fluorescence to Varicella Zoster virus in 2 (Cases 8 and 9) of 4 cases in which CSF smears were examined. The cells showing fluorescence were $10.5 \%$ in the former and $1.5 \%$ in the latter. Pleocytosis was found in all cases and CSF cell counts ranged from 52 to $2,000 / 3 \mathrm{~mm}^{3}$ in the early stage. In 3 cases immunoglobulin containing cells ( $\operatorname{IgG}$ and $\operatorname{IgM}$ ) were seen about $2-20 \%$ within 2 weeks of onset. IgG contents in all and IgG\% in 8 of 9 cases, IgA concentration in 7 and $\operatorname{IgA} \%$ in 7 of 9 cases were increased. These results support the view that the Varicella Zoster virus spreads to the meninges and CSF from ganglions in patients with Ramsay Hunt's syndromes. - Ramsay Hunt's syndrome; CSF
\end{abstract}

Ramsay Hunt's syndrome is characterized by the symptoms of peripheral facial palsy with herpes zoster oticus and acoustic nerve symptoms such as vertigo, tinnitus and hearing disturbance (Hunt 1907). In general, it has been considered that these symptoms are due to a herpetic inflammation of the geniculate ganglion and to an extension of the inflammatory process to the adjacent facial and acoustic nerves (Hunt 1907).

The process of the inflammatory extension of the disease, however, has not been clarified except in the case of herpes zoster which is due to infection with Varicella Zoster virus (to be abbreviated as VZV).

The purpose of the present study is to carry out the immunological and cytological examinations of cerebrospinal fluid (CSF) in Ramsay Hunt's syndrome.

Received for publication, January 24, 1980. 
TABLE 1. Summary of laboratory findings

\begin{tabular}{|c|c|c|c|c|c|c|c|c|c|c|}
\hline \multirow{2}{*}{ Cases } & \multirow{2}{*}{$\begin{array}{l}\text { Sex \& } \\
\text { age }\end{array}$} & \multirow{2}{*}{$\begin{array}{l}\text { Affected } \\
\text { side }\end{array}$} & \multirow{2}{*}{$\begin{array}{l}\text { Days } \\
\text { from } \\
\text { onset }\end{array}$} & \multicolumn{2}{|c|}{$\underset{\text { titer }}{\mathrm{VZV} \text { antibody }}$} & \multicolumn{5}{|c|}{ Serum immunoglobulin } \\
\hline & & & & Serum & $\mathrm{CSF}$ & $\operatorname{IgG}$ & $\operatorname{IgM}$ & $\operatorname{IgA}$ & $\mathrm{C}_{3}$ & $\kappa / \lambda$ \\
\hline 1. T.K. & $\mathrm{F}, 53$ & $\mathrm{~L}$ & 23 & $\times 160^{*}$ & - & $1820^{*}$ & $630^{*}$ & 400 & - & - \\
\hline \multirow{2}{*}{ 2. K.I. } & F, 9 & $\mathbf{R}$ & 3 & $\times 80$ & - & 1460 & 250 & 166 & 142 & 1.70 \\
\hline & & & 31 & $\times 160^{*}$ & - & 1450 & 133 & 140 & 110 & 1.89 \\
\hline 3. G.O. & M, 74 & $\mathbf{R}$ & 15 & $\times 1280^{*}$ & $\times 4^{*}$ & 930 & 138 & 290 & 112 & - \\
\hline \multirow[t]{3}{*}{ 4. M.A. } & $\mathrm{F}, 46$ & $\mathrm{R}$ & 14 & $\times 160 *$ & $\times 2^{*}$ & 1230 & $660^{*}$ & 200 & 91 & 1.46 \\
\hline & & & 21 & $\times 320^{*}$ & $\times 2^{*}$ & 1080 & $340^{*}$ & 190 & 110 & 1.10 \\
\hline & & & 67 & - & - & 1490 & $490^{*}$ & 198 & 100 & 1.20 \\
\hline 5. A.H. & F, 48 & $\mathrm{R}$ & 17 & $\times 320^{*}$ & $\times 4^{*}$ & 1400 & $340^{*}$ & 280 & 100 & 1.20 \\
\hline \multirow[t]{6}{*}{ 6. A.I. } & M, 31 & $\mathrm{R}$ & 6 & $\times 160^{*}$ & $\times 4^{*}$ & 1340 & 115 & 415 & 160 & 1. 60 \\
\hline & & & 14 & $\times 160^{*}$ & $\times 4^{*}$ & 1280 & 105 & 330 & 160 & 1.55 \\
\hline & & & 35 & $\times 320^{*}$ & - & 1100 & 110 & 340 & 150 & 1.95 \\
\hline & & & 77 & $\times 1280^{*}$ & $\times 8^{*}$ & 1600 & $280^{*}$ & 250 & 170 & - \\
\hline & & & 107 & $\times 2560 *$ & $\times 4^{*}$ & 1630 & 165 & 285 & 172 & - \\
\hline & & & 169 & - & - & 1100 & 90 & 350 & 140 & - \\
\hline \multirow[t]{4}{*}{ 7. K.S. } & M, 71 & $\mathrm{R}$ & 4 & $\times 160^{*}$ & $\times 2^{*}$ & 540 & 265 & 180 & 91 & - \\
\hline & & & 12 & $\times 160^{*}$ & $\times 8^{*}$ & 1230 & $350^{*}$ & 200 & 91 & - \\
\hline & & & 26 & $\times 640^{*}$ & $\times 8^{*}$ & 1370 & 240 & 180 & 86 & - \\
\hline & & & 68 & - & $\times 4^{*}$ & - & - & - & - & - \\
\hline \multirow[t]{5}{*}{ 8. H.М. } & M, 68 & $\mathrm{~L}$ & 3 & - & - & 1250 & 76 & 260 & 150 & 1.05 \\
\hline & & & 7 & $\times 640^{*}$ & $\times 16^{*}$ & 1480 & 120 & 320 & 160 & - \\
\hline & & & 16 & - & $\times 8^{*}$ & 1320 & 160 & 170 & 120 & - \\
\hline & & & 24 & $\times 160^{*}$ & - & 1250 & 56 & 260 & 113 & 1.55 \\
\hline & & & 46 & - & - & - & - & - & - & - \\
\hline \multirow[t]{3}{*}{ 9. K.O. } & $\mathrm{F}, 62$ & $\mathrm{~L}$ & 4 & $\times 640^{*}$ & $\times 8^{*}$ & 1120 & 245 & 110 & 116 & 0.93 \\
\hline & & & 6 & - & - & 1520 & 185 & 220 & 100 & - \\
\hline & & & 10 & $\times 160^{*}$ & $\times 8^{*}$ & - & - & - & - & - \\
\hline Total & $\begin{array}{l}\mathrm{M}: 4 \\
\mathrm{~F}: 5 \\
9-74\end{array}$ & $\begin{array}{l}\mathrm{L}: 3 \\
\mathrm{R}: 6\end{array}$ & & $9 / 9$ & $7 / 7$ & $1 / 9$ & $5 / 9$ & $0 / 9$ & $0 / 9$ & $0 / 9$ \\
\hline
\end{tabular}

* Significant increases from control values.

\section{Subjects And Methods}

Subjects. The subjects consisted of 9 patients with Ramsay Hunt's syndrome among 85 patients with acute facial palsy who were admitted to our division during the period from January, 1972 to March, 1978. They included 4 males and 5 females at 9 to 74 years of age. Five patients were admitted within 2 weeks following onset of the palsy and 4 were after 2 weeks (Table 1). The side of facial palsy was right in 6 cases and left in 3 cases. Herpetic vesicles were seen at the onset of facial paralysis in 8 cases, but in one case (Case 6) not until the 5th day of paralysis.

Methods. The patients first underwent physical and neurological examinations and the affected region was determined.

All samples obtained from each patient were examined on one run, the sera and CSF being stored at $-20^{\circ} \mathrm{C}$ until testing. Serum immunoglobulin and $\kappa / \lambda$ were estimated by single radial immunodiffusion (Mancini et al. 1965), while CSF immunoglobulin was determined by electro-immunodiffusion (Takase 1975). Varicella Zoster (VZ) antibodies in serum and in CSF were measured by indirect immunofluorescence. Furthermore, about $5 \mathrm{ml}$ of CSF was withdrawn by lumbar puncture and subjected to general examination, while CSF smear were prepared with a Tomy cell collection apparatus. These slides were immediately dried, fixed in cold acetone for $10 \mathrm{~min}$ and stored at $-20^{\circ} \mathrm{C}$.

Study of immunoglobulin containing cells (IgG or IgM) in CSF was performed by the 
from 9 cases of Ramsay Hunt's syndrome

\begin{tabular}{|c|c|c|c|c|c|c|c|c|c|c|}
\hline N.A. & Pandy & $\begin{array}{c}\text { Cell } \\
\text { counts } \\
\left(n / 3 \mathrm{~mm}^{3}\right)\end{array}$ & $\begin{array}{c}\text { Protein } \\
(\mathrm{mg} / 100 \mathrm{ml})\end{array}$ & $\operatorname{IgG}$ & IgG\% & $\operatorname{IgA}$ & $\operatorname{IgA} \%$ & $\begin{array}{c}\text { Sugar } \\
(\mathrm{mg} / 100 \mathrm{ml})\end{array}$ & $\mathrm{Cl}$ & Try. \\
\hline- & - & $169 *$ & 37 & $5.8^{*}$ & $15.7^{*}$ & n.d. & - & 53 & 119 & - \\
\hline \pm & + & $271^{*}$ & $160^{*}$ & $6.5^{*}$ & 4.0 & $2.5^{*}$ & 1. $6^{*}$ & 64 & 121 & - \\
\hline- & - & 13 & 7 & 1.45 & $20.0^{*}$ & n.d. & - & 59 & 123 & - \\
\hline- & + & $18^{*}$ & 44 & $5.0^{*}$ & 11.3 & $2.95^{*}$ & $5.7^{*}$ & 57 & 122 & \pm \\
\hline- & + & $269^{*}$ & 27 & 5. $20^{*}$ & $19.1^{*}$ & $0.48^{*}$ & $1.8^{*}$ & 64 & 122 & \pm \\
\hline- & \pm & $138^{*}$ & 33 & 2.61 & 7.8 & n.d. & - & 63 & 122 & - \\
\hline- & + & 9 & 35 & 4. $00^{*}$ & 11.4 & 0.20 & 0.57 & 62 & 121 & - \\
\hline- & + & $52 *$ & 16 & $3.90^{*}$ & $24.0^{*}$ & $0.48^{*}$ & 3. $0^{*}$ & 57 & - & - \\
\hline+ & + & $2000^{*}$ & $144^{*}$ & $10.50^{*}$ & 7.3 & 1. $95^{*}$ & 1. $6^{*}$ & 42 & 123 & + \\
\hline+ & + & $246^{*}$ & 33 & $5.00^{*}$ & $15.1^{*}$ & 1. $80^{*}$ & $5.4^{*}$ & 51 & 123 & - \\
\hline \pm & + & $88^{*}$ & 28 & 2.80 & 10.0 & $0.43^{*}$ & $1.5^{*}$ & 66 & 123 & \pm \\
\hline- & \pm & $23 *$ & 44 & 4. $65^{*}$ & 10.5 & 2. $60^{*}$ & $5.9 *$ & 61 & 124 & - \\
\hline- & + & $19^{*}$ & 40 & 4. $0^{*}$ & 10.0 & 2. $15^{*}$ & $5.4^{*}$ & 59 & 125 & - \\
\hline \pm & + & $21^{*}$ & 37 & $3.60^{*}$ & 10.0 & $0.4^{*}$ & 0.1 & 67 & 125 & - \\
\hline+ & $H$ & $224^{*}$ & 38 & 4. $30^{*}$ & 11.3 & 0.32 & 0.8 & 48 & 125 & - \\
\hline- & + & $154^{*}$ & 34 & 3. $20^{*}$ & 9.4 & $0.36^{*}$ & 1.1 & 54 & 126 & + \\
\hline- & + & 12 & 5 & 2.10 & $42.0^{*}$ & 0.16 & $3.2^{*}$ & 42 & 124 & - \\
\hline- & + & $19 *$ & 31 & $3.30^{*}$ & 10.6 & 0.31 & 1.0 & 44 & 121 & - \\
\hline- & + & $1500^{*}$ & $128^{*}$ & $31.0^{*}$ & $24.2^{*}$ & $4.4^{*}$ & $3.4^{*}$ & 51 & 124 & + \\
\hline \pm & + & $504^{*}$ & $58^{*}$ & $19.4^{*}$ & $33.4^{*}$ & 3. $0 *$ & $5.1^{*}$ & 46 & 124 & + \\
\hline \pm & + & $214^{*}$ & $74^{*}$ & $9.2^{*}$ & 12.4 & 3. $0^{*}$ & $4.1^{*}$ & 50 & 121 & + \\
\hline- & \pm & $67^{*}$ & 28 & 8. $20^{*}$ & $29.2^{*}$ & $2.45^{*}$ & $8.8^{*}$ & 52 & 122 & - \\
\hline- & + & $29 *$ & 45 & 7. $20^{*}$ & $16.0^{*}$ & 1. $37^{*}$ & 3. $0^{*}$ & 50 & 124 & - \\
\hline- & + & $214 *$ & 40 & $5.30^{*}$ & $13.3^{*}$ & - & - & 48 & 122 & + \\
\hline- & + & $186^{*}$ & 25 & - & - & - & - & 62 & 121 & - \\
\hline- & \pm & $87^{*}$ & 30 & - & - & - & - & 53 & 124 & - \\
\hline $1 / 9$ & $8 / 9$ & $9 / 9$ & $3 / 9$ & $9 / 9$ & $8 / 9$ & $7 / 9$ & $7 / 9$ & $0 / 9$ & $0 / 9$ & $3 / 9$ \\
\hline
\end{tabular}

n.d., not detectable; N.A., Nonne Apelt test.

direct immunofluorescence method (Dayan and Stokes 1973). Immunofluorescent staining of viral antigens (Varicella Zoster virus and Herpes Simplex virus) in CSF smears was examined with the direct method using VZ FITC Rabbit Antiserum (Flow Lab. Inc., Lot No. 45667004) or Herpes Hominis FITC Rabbit Antiserum (Toshiba Phar. Co., Ltd., No. 08-307).

\section{Results}

Serum immunoglobulins. Total protein and its fractions of serum were within a normal range in all samples.

Among the serum immunoglobulins, IgG in 1 and $\operatorname{IgM}$ in 5 of 9 cases increased, but values of $\operatorname{IgA}$ and $\mathrm{C}_{\mathbf{3}}$ were within normal ranges. In the patients with raised IgM levels, the duration from onset to admission was from 4 to 23 days (Table 1).

$V Z$ antibody titer in serum and in CSF. The indirect immunofluorescent antibody titer of VZV in serum was elevated more than 160-fold in all 9 cases (Table 1). Five of them showed a four-fold increase in VZ antibody. The VZ antibody 
titer in CSF was significantly elevated in all of 7 examined cases above control values, while no such antibody was detected in 10 healthy subjects.

Detection of antigen of $V Z V$ in $C S F$. There was positive fluorescence to VZV in 2 (Cases 8 and 9) of 4 cases (Cases 6, 7, 8 and 9) in which CSF smears were examined. The cells showing fluorescence (Fig. 1) were detected on the 3rd and 4th days after onset and numbered $10.5 \%$ and $1.5 \%$, respectively.

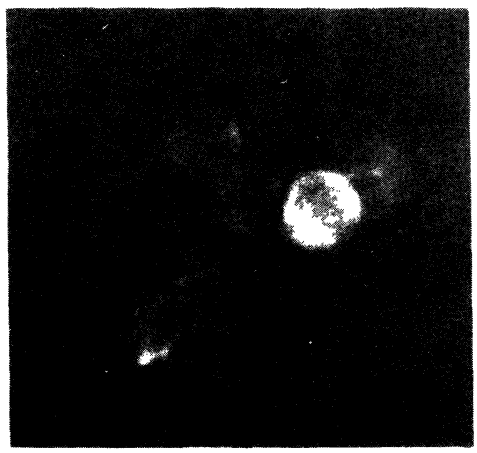

Fig. 1. CSF cells showing specific fluorescence for Varicella Zoster antigens. $\times 400$.

CSF findings. The total number of lumbar punctures performed in the 9 cases was 26, including 9 within 2 weeks from onset and 17 punctures thereafter. Nonne Apelt test showed positive results in 3 of 26 trials, while positive Pandy results were obtained in 24 of 26 . The total protein content was elevated 5 times, 4 of their samples having been obtained within 20 days from onset. Pleocytosis was found in all cases and CSF cell counts ranged from 52 to $2,000 / 3 \mathrm{~mm}^{3}$ within 20 days from onset, but they gradually returned to the normal range by about the 4 th week after onset. The CSF cytograms of 3 patients (Cases 7,8 and 9) are summarized in Table 2 . In the early stage, there were large quantities of

TABLE 2. CSF cell counts, cytogram and immunoglobulin containing cells

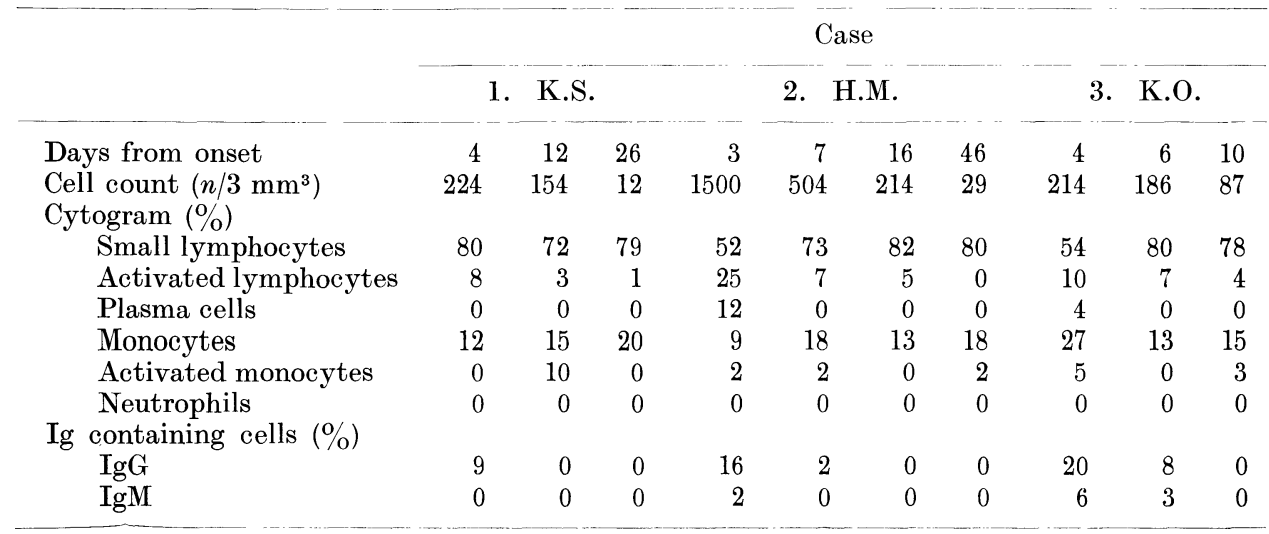


small lymphocytes, and activated lymphocytes ranged from 3 to $25 \%$. In Case 8 , immature plasma cells were predominantly seen on the 5th day from onset (Fig. 2).

In 4 patients immunoglobulin containing cells (IgG) constituted $2-20 \%$ within 2 weeks of onset and they disappeared after about 20 days, whereas IgM cells constituted $2-6 \%$ within 5 days from onset (Fig. 3 ).
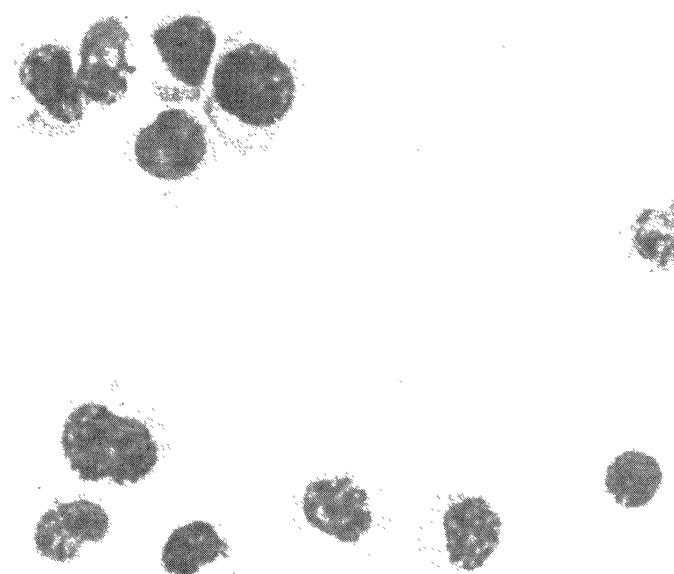

Fig. 2. Large quantities of immature plasma cells in CSF. May-Grünwald Giemsa stain, $\times 400$.

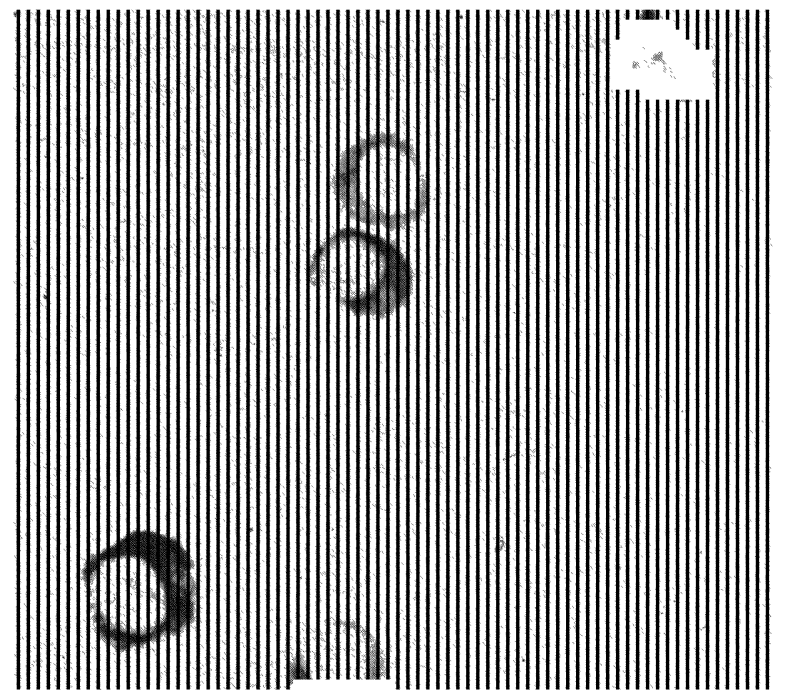

Fig. 3. IgG containing cells in CSF. $\times 400$.

Immunoglobulin concentrations in CSF. IgG contents (mean \pm s.D.; $1.60 \pm 0.71$ $\mathrm{mg} / 100 \mathrm{ml}$ in control) were increased in all cases, whereas the IgG percentage 
$(6.81 \pm 2.45 \%$ in control) was elevated in 8 of 9 cases. IgA contents $(0.21 \pm 0.09$ $\mathrm{mg} / 100 \mathrm{ml}$ in control) were elevated in 7 of 9 patients, but in 1 case (Case 1) it was not detected. The percentage of $\operatorname{IgA}$ increased in 7 of 9 cases.

Sugar and chloride were within normal ranges in all cases.

\section{Discussion}

In reference to the cause of herpes zoster oticus in Ramsay Hunt's syndrome, Aitken and Brain (1933) first reported significant increases of VZ antibody titers in serum in 9 cases. In addition, Tomita and Hayakawa (1972) also found significant increases of CF antibody titer to VZV in 18 out of 22 patiens with clinical herpes zoster oticus and concluded that this disease is due to infection caused by VZV.

In addition to these reports on virological findings, the isolation of virus from the affected posterior spinal ganglia (Bastian et al. 1974; Shibuta et al. 1974) and its pathological findings (Ghatak and Zimmerman 1973) in patients with herpes zoster would certainly support the above-mentioned consideration. To our knowledge, however, there have been only a few reports of VZ antibody in CSF of Ramsay Hunt's syndrome.

Recently, the presence of antibodies to virus in CSF has suggested the existence or preexistence of virus in CSF and possibility of the production of local antibody to the virus (MacCallum et al. 1974; Cappel et al. 1975), although such results have been interpreted as due to increased permeability of the blood brain barrier.

Djupesland et al. (1975) examined 4 cases of Ramsay Hunt's syndrome and found 1 case with significantly raised CF antibody in CSF. In addition, Aleksic et al. (1973) and Engelhardt (1976) also found 1 case each with elevated CF titer in CSF. Our findings of a significant elevation of this antibody titer in CSF in all of 7 examined cases are consistent with the previous reports.

Furthermore, many authors have pointed out the pleocytosis in CSF exists in many cases of not only Ramsay Hunt's syndrome, but also Varicella Zoster infectious diseases. For instance, Gold (1966) found 8 cases (38\%) of pleocytosis among 21 cases of herpes zoster situated in cervical, thoracic and lumbar segments. Carter (1951) found pleocytosis in $14(32 \%)$ of 44 cases, but no clinical symptoms of headache or meningeal irritation were reported in these studies.

According to the present data, there was pleocytosis in CSF in all cases, particularly during the first 20 days from onset when pleocytosis ranged from 52 to $2,000 / 3 \mathrm{~mm}^{3}$. There were, however, no meningeal symptoms except slight headache and low grade fever in Case 6.

These results seem to suggest that pleocytosis in CSF usually exists subclinically without meningeal symptoms in patients with herpes zoster.

Studies of immunoglobulin containing cells in CSF have been performed by Guseo (1974) and Dayan and Stokes (1973). Guseo examined 3 cases of lymphocytic meningitis and reported that plasma cells, immature plasma cells and large transformed cells have positive fluorescence. Dayan and Stokes (1973) studied 95 
patients with viral encephalitis diagnosed by serological examination and reported in detail the correlation between the clinical course and the appearance of immunoglobulin containing cells. In the present study, immunoglobulin containing cells were detected in all samples examined within 5 days from onset - a finding which is in good agreement with that of Dayan and Stokes (1973).

These data suggest that CSF cells may have an important role in the development of humoral and cellular immunity. Furthermore, Shoji et al. (1976) presented an immunofluorescent demonstration of $\mathrm{VZ}$ antigen in the CSF cells fixed with acetone in a case of herpes zoster meningitis and, based upon this result, presumed that herpes zoster meningitis develops from the ganglionitis.

We also detected immunofluorescent positive cells of VZ antigen in 2 specimens from CSF smears using the same method.

The presence of $\mathrm{VZ}$ antibody and immunoglobulin containing cells in CSF in Ramsay Hunt's syndrome suggest that VZV resulting from ganglionitis may spread to the CSF cavity and induce the inflammatory reaction in CSF.

Cytological examination of CSF is now considered to be very important for determinining the pathogenesis of central nervous system infectious diseases, but cytograms in CSF have rarely been studied in cases of Ramsay Hunt's syndrome. The cell types in CSF of 3 of 9 patients were almost entirely mononuclear: 52$82 \%$ small lymphocytes, $1-25 \%$ activeted lymphocytes and $0-14 \%$ plasma cells at the early stage following onset. Polymorphonuclear leukocytes were not seen. These findings correlate well with those from studies on viral meningitis (Oehmichen 1976).

Estimation of CSF immunoglobulin is undoubtedly one of the most important procedures in investigating the pathomechanism of various neurological diseases, and significant progress has been made especially with regard to CNS infectious diseases. In a study of viral meningitis, Kalder and Ferris (1969) found increased IgG and IgA concentrations in CSF at about 4 days from onset. In addition, Link and Müller (1971) reported increased IgG percentage, and increased IgG percentage and $\operatorname{IgA}$ percentage were described by Schneck and Claman (1969).

Based upon the results of serum immunoglobulin and CSF immunoglobulin studies, Takase (1975), one of the present authors, has made a classification of neurological diseases. He noted that the category indicating abnormalities of serum immunoglobulin, raised IgG, IgG percentage or IgA percentage of CSF indicates diseases which are basically systemic inflammatory reactions of CNS, including various infectious diseases.

Our findings support the idea that Ramsay Hunt's syndrome is a systemic disease caused by VZV and that the rise in immunoglobulin values in CSF indicates the presence of an inflammatory reaction within the CNS.

Finally, from the above-mentioned results and the reports by many authors, we may presume that the inflammation caused by VZV is not localized to the neighborhood of the geniculate ganglia, although the main site of inflammatory lesion is there. Furthermore, the VZV induces the skin eruptions while it 
simultaneously invades the CSF cavity and induces an inflammatory reaction there.

\section{References}

1) Aitken, R.S. \& Brain, R.T. (1933) Facial palsy and infection with zoster virus. Lancet, 224, 19-22.

2) Aleksic, S.N., Budzilovich, G.N. \& Lieberman, A.N. (1973) Herpes zoster oticus and facial paralysis (Ramsay Hunt's syndrome). Clinico-pathologic study and review of literature. J. Neurol. Sci., 20, 149-159.

3) Bastian, F.O., Rabson, A.S., Yee, C.L. \& Tralka, T.S. (1974) Herpesvirus varicellae. Isolated from human dorsal root ganglia. Arch. Path., 97, 331-333.

4) Cappel, R., Thiry, L. \& Clinet, G. (1975) Viral antibodies in the CSF after acute CNS infections. Arch. Neurol. 32, 629-631.

5) Carter, A.B. (1951) Investigation into the effects of aureomycin and chloramphenicol in herpes zoster. Brit. med. J., 1, 987-991.

6) Dayan, A.D. \& Stokes, M.I. (1973) Rapid diagnosis of encephalitis by immunofluorescent examination of cerebrospinal fluid cells. Lancet, 1, 177-179.

7) Djupesland, G., Berdal, P., Johannessen, T.A., Degré, M., Stien, R. \& Skrede, S. (1975) The role of viral infection in acute peripheral facial palsy. Acta otolaryngol., 79, 221-227.

8) Engelhardt, P. (1976) Liquorbefunde bei ein-, doppel- und wechselseitigen Fazialisparesen. Med. Klin., 71, 706-710.

9) Ghatak, N.R. \& Zimmerman, H.M. (1973) Spinal ganglion in herpes zoster. A light and electron microscopic study. Arch. Path., 95, 411-415.

10) Gold, E. (1966) Serologic and virus-isolation studies of patients with varicella or herpes-zoster infection. New Engl. J. Med., 274, 181-185.

11) Guseo, A. (1974) Immunoglobulin-containing cells in the cerebrospinal fluid. Neuropath. Pol., 12, 281-285.

12) Hunt,J.R. (1907) Herpetic inflammation of the geniculate ganglion. A new syndrome and its complications. J. Nerv. Ment. Dis., 34, 73-96.

13) Kalder, J. \& Ferris, A.A. (1969) Immunoglobulin levels in cerebrospinal fluid in viral and bacterial meningitis. Med. J. Aust., 2, 1206-1209.

14) Link, H. \& Müller, R. (1971) Immunoglobulins in multiple sclerosis and infections of the nervous system. Arch. Neurol., 25, 326-344.

15) MacCallum, F.O., Chinn, I.J. \& Gostling, J.V.I. (1974) Antibodies to herpes-simplex virus in the cerebrospinal fluid of patients with herpetic encephalitis. $J$. med. Microbiol., 7, 325-331.

16) Mancini, G., Carbonara, A.O. \& Heremans, J.F. (1965) Immunochemical quantitation of antigens by single radial immunodiffusion. Immunochemistry, 2, 235-254.

17) Oehmichen, M. (1976) Cerebrospinal Fluid Cytology. An Introduction and Atlas. Georg Thieme Publishers, Stuttgart, pp. 126-131.

18) Schneck, S.A. \& Claman, H.N. (1969) CSF immunoglobulins in multiple sclerosis and other neurological diseases. Arch. Neurol., 20, 132-139.

19) Shibuta, H., Ishikawa, T., Hondo, R., Aoyama, Y., Kurata, K. \& Matsumoto, M. (1974) Varicella virus isolation from spinal ganglion. Arch. ges. Virusforsch., 45, 382-385.

20) Shoji, H., Koya, M. \& Ogawara, H. (1976) Meningitis associated with herpes zoster. Immunofluorescent demonstration of varicella-zoster antigens in CSF cells. $J$. Neurol., 213, 269-271.

21) Takase, S. (1975) Quantitative analysis of immunoglobulins in cerebrospinal fluid and relationship between alterations of CSF fractions and neurological diseases. The Physico-Chemical Biology (Tokyo), 18, 79-89. (Japanese)

22) Tomita, H. \& Hayakawa, W. (1972) Varicella-zoster virus in idiopathic facial palsy. Arch. Otolaryngol., 95, 364-368. 